\title{
Teenagers' Motive in Cyberbullying Against Micro-Celebrities on Social Media
}

\author{
Afrania Annastria ${ }^{\mathrm{a}, 1^{*}}$, Medo Maulianza ${ }^{\mathrm{b}, 2}$, Anindita Lintangdesi A ${ }^{\mathrm{c}, 3}$, and Nur Asni Gani ${ }^{\mathrm{d}, 4}$ \\ ${ }^{a, b, c, c}$ Sekolah Tinggi Ilmu Komunikasi Interstudi \\ ${ }^{d}$ Universitas Muhammadiyah Jakarta \\ Email: ${ }^{1}$ af.annastri30@gmail.com*; ${ }^{2}$ medomaulianza@gmail.com; ${ }^{3}$ lintangdesi@gmail.com; ${ }^{4}$ nurasnimaulianza@gmail.com \\ *corresponding author
}

\author{
Keywords: \\ Motive, Teenagers, Cyberbullying, \\ Micro Celebrity, Social Media
}

\begin{abstract}
Cyberbullying is a form of social media abuse most often carried out by teenagers because there are no specific requirements to examine how to use social media. Uniquely, the impact of cyberbullying in Indonesia can make victims viral and famous categorized as Micro-Celebrities. Micro-Celebrities are the ones famous for their content broadcasted through social media. This research aims to explain teenagers' motives in doing cyberbullying against Micro-Celebrities through social media. The research method used is descriptive qualitative with a phenomenology approach. Data is collected through in-depth interviews with female teenage informants $15-17$ years of age. The research was conducted at SMAN 4, Bekasi City, located in a suburban area where most teenagers are heavy social media users. Summary of research result shows that teenagers' motives to do cyberbullying against Micro-Celebrities are: (1) feeling dislike of micro-celebrities personality; (2) intending to insinuate with unethical negative comments; (3) feeling envious and intending to incite; (4) feeling that micro-celebrities do not deserve popularity when compared to macro-celebrities. Cyberbullying by teenagers against micro-celebrities is in the form of negative comments in the comments column. These micro-celebrities are being bullied because they are considered to have gained popularity by spreading harmful content. Teenagers disagree with celebrities who are instantly famous because it is very unfair to celebrities who have creations and positively benefit society.
\end{abstract}

Copyright $\odot 2021$ Channel Jurnal Komunikasi. All right reserved.

\section{INTRODUCTION}

The utilization of information and communication technology has been progressing in the interests of its users. One of the advances in information and communication technology is the internet. The internet has now become a necessity of life for the community. Statistical data on the number of Indonesian internet users reached 196 million out of 266 million people, or $73.7 \%$ of people connected to the internet (Katadata.co.id, 2020). People use the internet to find the most meaningful possible information. The internet is also used as a communication medium or commonly known as social media. Social media allows people to share information, make friends, and build self-image. The use of social media today is like a double-edged knife. On the one hand, social media is beneficial and makes it easier for people to live a higher quality of life. However, on the other hand, social media also has a negative impact when it is misused. Misuse of social media occurs because there are no special requirements for having activities on social media to give people the freedom to use.

Those who use social media the most are teenagers, as stated in the results of a survey by the Indonesian Internet Service Providers Association (APJII) that the majority of internet users in Indonesia are people aged 15 to 19 years (Pratomo, 2019). In addition to making friends and Building self-image, teenagers also use social media to comment on other people's status or posts (Fronika, 2019). The concern is that not all teenagers understand how to use social media correctly. Teenagers with vulnerable emotions are unstable and easily influenced, so that they have an excellent opportunity to abuse social media (Natalia, 2016). One of the social media abuses that teenagers often do is Cyberbullying. 
Definition of Cyberbullying is bullying behavior that often occurs in various technological media today, in the form of an aggressive act attacking and deliberately carried out by individuals or groups using electronic media, repeatedly and from time to time against victims who do not have the power to defend themselves. Another definition of cyberbullying is aggressive acts committed to other individuals through electronic mail (email), private chat rooms or social media groups, websites, or digital messages or images sent to cell phones, to comments on personal social media accounts (Olweus, 2012). Cyberbullying is an act of judgment aimed at hurting other individuals psychologically due to an imbalance of power. In this case, the imbalance of power can be seen from differences in physical and social status. Those who considered themselves to have a higher position think that they can do cyberbullying to others who are lower in position. Alternatively, people who feel physically perfect send negative comments on the victim's personal social media account.

Cyberbullying among teenagers has become a common thing as stated in the results of research by a student of Andalas University in Padang that out of 353 teenagers who become informants, $78 \%$ of informants had seen cases of cyberbullying, $21 \%$ had committed cyberbullying, and $49 \%$ had been victims of cyberbullying (Sartana \& Afriyeni, 2017). The types of cyberbullying that teenagers often do include: 1) rude comments, 2) uploading stories, 3) uploading photos, and 4) commenting on posts (Fitransyah \& Waliyanti, 2018). Cyberbullying by teenagers is undoubtedly triggered by a particular impulse which becomes the reason teenagers do cyberbully. These impulses are usually called motives.

Motive is a driving force that becomes a reason or impulse in humans to do something (Ardianto \& Komala, 2004). The results of research on cyberbullying motives by teenagers against other teenagers on social media are as follows: feeling dislike of someone or someone's personality, intending to insinuate with unethical and harsh negative sentences, aiming to entertain users or internet users to laugh, feeling envious and intending to incite teenagers, and feeling that they are better as well as more qualified than others, so they think that cyberbullying is a natural thing (Marsinun \& Riswanto, 2020).

Cyberbullying can negatively impact psychological harm to its victims, namely feelings of sadness, hurt, anger, frustration, confusion, stress, distress, and loneliness (Cassidy et al., 2013). Victims of cyberbullying are more vulnerable and more likely to develop depression that leads to suicide. These depression factors are because victims of cyberbullying can be bullied anytime and anywhere. However, it is different from the phenomenon that occurs in Indonesia. When someone becomes a victim of cyberbullying on social media, the effect is unique, namely that the victim can become viral and famous (Mutma, 2017). This phenomenon gives a new perception that the more you are bullied, the more viral and famous it will be. The more viral and famous, the more prosperous it will be. Instead of getting psychological harm, victims bullied on social media are getting more famous and gaining financial benefits (Situmorang, 2019). Victims of cyberbullying in Indonesia benefit because their name immediately goes viral in a fairly instant way, or commonly referred to as an impromptu artist. This phenomenon brings up a new concept. One concept that has recently emerged in social media is micro-celebrity which is defined as a new form of online performance that includes an increase in popularity through web technologies such as videos, blogs, and social media (Senft, 2008).

Micro-celebrities are celebrities born through social media. There are two types of micro-celebrities, achieved and ascribed (Marwick \& Boyd, 2011). Micro-celebrity achieved is a celebrity label based on an individual's choice of consciously increasing visibility, status, popularity. It is like being an online model or hosting a video show, usingwhile ascribed micro-celebrities are celebrity labels that are obtained due to the influence of media production, such as paparazzi or blog post gossip (Sadasri \& Sosio, 2017). However, this research focuses on ascribed micro-celebrities because they get their existence and recognition on social media as they Are victims of cyberbullying. Based on the research on micro-celebrities by Gajah Mada University students, Awkarin is an example of micro-celebrity. Awkarin grabs people's attention because she always uploads photos and videos that contained controversy. Awkarin often uploads romantic photos of herself with her boyfriend or uploads photos of herself smoking and drinking alcohol with her friends. Not only that, but Awkarin also always expresses harsh words in her uploaded videos and photo captions. Awkarin's behavior draws scorn from Indonesian people (Simangunsong, 2018).

Regardless of Awkarin, who had a positive impact from cyberbullying with a micro-celebrity status that instantly increased her popularity on social media, Awkarin also had the negative impact of cyberbullying. Awkarin, famous and blasphemed for his sexy looks, lifestyle, and controversy over her videos filled with swearing and harsh words, has left her inundated with likes and scorns on her social media. Awkarin had to hire a bodyguard and turned off the comments column to feel insecure in facing the harsh comments from her followers. The harsh comments greatly affected Awkarin's psychological condition. Because of her phenomenal content and account, Awkarin has become an idol for her fans and targets bullying. Many teenagers who subscribe to her YouTube account love it and follow every activity of her life.

Barbie Kumalasari has recently famous for being a cyberbullying victim on social media. It began with Barbie's husband, Galih Ginanjar, who was caught in a case and languished in the Jakarta Metro Police to insult his ex-wife Fairuz A Rafiq YouTube social media. Galih was sued for defamation. Then, Barbie Kumalasari, who always represented Galih Ginanjar to talk about his case, is considered to have taken the opportunity to be recognized by many people. She even released a song with her mediocre voice. Barbie did not deny that the news about her defeated the prestige of well-known Indonesian artists, even though the content was only bullying or insulting her (Waluyo, 2019). 
Cyberbullying cases against Micro-Celebrities still go unnoticed because there is no specific legal system to examine cyberbullying, especially in Indonesia. Another factor, due to lack of public knowledge about media literacy, especially internet ethics, does not rule out the possibility of cases like Awkarin and Barbie Kumalasari emerging.

Since there are many cases of cyberbullying against micro-celebrities that certainly have a psychological impact on the victim, researchers intend to examine more deeply about cyberbullying from the perspective of teenagers who use social media to satisfy their needs. Teenagers are the ones who use social media the most and have an excellent opportunity to do cyber bullying. The motivation that exists is an impulse for the perpetrator to do cyber bullying against others. This underlies the research to determine the teenagers' motivation in cyberbullying micro-celebrities on social media.

\section{A. Social Media}

Andreas Kaplan and Michael Haenlein defined social media as a group of internet-based applications built based on Web 2.0 ideology and technology. This technology enables the creation and exchange of user-generated content. Social media comes in many different forms, including social networks, internet forums, weblogs, social blogs, microblogging, wikis, podcasts, images, videos, ratings, and social bookmarking. There are six types of social media: collaboration projects (e.g., Wikipedia), blogs and microblogs (e.g., Twitter), content communities (e.g., YouTube), social networking sites (e.g., Facebook, Instagram), virtual games (e.g., the world of warcraft), and virtual social (e.g., second life) (Kaplan \& Haenlein, 2010).

Social media is a tool that connects a person with friends to communicate and exchange information by creating a personal account on specific sites. The biggest websites which are popular and are most commonly used today are Instagram, YouTube, Twitter, and Facebook. Social media is a different means of communication because it has an online system and uses the internet for information distribution. This system allows someone to efficiently do their activities, either quickly uploading or commenting on other individual uploads without time constraints (timeless).

Therefore, social media users are free to comment on everything that has been uploaded and can respond directly and openly. These features have led to significant phenomena in the flow of information both globally and in Indonesia. Due to these things, social media also has a dark side from a society that misuses social media for negative things. One of the most worrying abuses of social media is Cyberbullying.

\section{B. Cyberbullying}

Cyberbullying is bullying behavior that often occurs in various technological media (Ireland et al., 2018). In the digital era like today, the rapid development of technology makes it very easy for people to think about something. Only by using a cell phone can people express their opinion to the public. It becomes negative when a person or group of people uses technology to commit deliberate, aggressive actions and goes without norms limitation to the victims who are weaker and unable to defend themselves.

Cyberbullying is an act of aggression committed against others through electronic mail, digital messages, chat rooms, websites, or images sent to someone's cell phone. Usually, cyberbullying often occurs in the popular media for a certain period and in certain age groups (Kowalski \& Limber, 2013).

Cyberbullying has become increasingly prevalent, one of which is the increasing number of social media platforms that are the most frequently used, such as Instagram, YouTube, Twitter, Facebook, and various digital messaging applications. These various platforms are currently popular and can be accessed by anyone, anywhere, and anytime. Various groups can access them, from children, teenagers to the elderly. This fact makes it easier for someone to become the perpetrator or victim of Cyberbullying.

Cyberbullying is similar to traditional bullying. As is the case with traditional bullying, cyberbullying is also an act of aggression that provides psychological harm to the victim, which is usually repeated from time to time and occurs between individuals who have an imbalance of power (Kowalski et al., 2014). The factor that causes cyberbullying perpetrators other than easy digital access is a factor of power imbalance. The power imbalance can range from an imbalance of position to physical. A person will feel powerful when he is in a higher position than other individuals.

Regardless of the similarities between traditional bullying and cyberbullying, these two things also have differences. Namely, the traditional bullying occurring at school is only felt by the victim while in school. No more bullying occurs when the victim returns home. However, it is different from cyberbullying, which can happen anytime and anywhere (Rosen et al., 2017).

\section{Micro-Celebrity}

Celebrities have social functions and are positioned as representations, discourses, and industrial and cultural formations so that celebrities provide a rich body of semiotic texts and discourse (Garman, 2014). A celebrity in another language is someone who has an existence in various circles of society. Celebrities or often called artists or new names, 
namely influencers, usually do activities related to the crowd, including public debate, enthusiasm, and even giving persuasive opinions that can influence public interest toward something. It increasingly shows the significance of the celebrity theory on a concept development that comes from the characteristics of new media, namely the internet with an online system that allows easy and fast interaction between individuals. This online system is the basis for the emergence of a new concept, namely micro-celebrities (Sadasri \& Sosio, 2017).

The micro-celebrity concept involves the use of videos, blogs, and social networking sites to achieve celebrity status. Initially, interactive blogging through personal and political commentary on discussion sites was in the mid1990s (McQuail, 2011). Micro-celebrities become famous through content spread on social media which can grab the public's attention. Nowadays, most people who are considered micro-celebrities are well-known intentionally or unintentionally through content uploaded on social media. The micro-celebrities become legitimate when the content contains achievements and benefits the community. However, the unique thing is that micro-celebrities in Indonesia are often famous for their controversial content (Situmorang, 2019). Social media becomes a demotic turn for microcelebrities that can increase the visibility of "ordinary people" who can make them celebrities (Garman, 2014). Now everyone has relatively more accessiblecyber bullying and faster access to becoming a celebrity through social media with an online system.

The shifts in technology, entertainment media, and the cultural conditions of celebrity worship created what we later called micro-celebrity, which are constructed as self-promotion. Celebrities are positioned in community culture as models of pervasive behavior, and their identities are closely related to public discourse (Marwick \& Boyd, 2011). The micro-celebrity phenomenon is growing by accessing the internet and social media sites, including in Indonesia. The concept of micro-celebrity is unique because the internet and social media are means for promotion and self-presentation. People are always looking for and finding micro-celebrity fame through content disseminated on social media, then redistributing the disseminated content, so that people indirectly start marketing new micro-celebrity candidates that are potential to have significant public influence (Sadasri \& Sosio, 2017).

\section{RESEARCH METHOD}

This research applies a qualitative method with a phenomenological approach, which describes a general meaning of various individual life experiences related to concepts or phenomena (Creswell, 2017). The purposive sampling technique is used to select informants. The informants in this research are three students from SMAN 4, Bekasi city, social media users, and perpetrators of cyberbullying against micro-celebrities.

The characteristics of Informants are as follows:

\begin{tabular}{lllll}
$\begin{array}{l}\text { Informan } \\
\text { Code }\end{array}$ & Age & Gender & Social Media & Cyberbullying Status \\
\hline I1 & 16 years old & Female & Twitter, Instagram, Youtube & Perpetrator \\
\hline I2 & 15 years old & Female & Instagram, Youtube & Perpetrator \\
\hline I3 & 17 years old & Female & Facebook, Instagram & Perpetrator \\
\hline
\end{tabular}

Table 1. Informant Characteristics

Bekasi City is chosen as the research location because it is a suburban city where the average teenagers are heavy social media users (Pramiyanti et al., 2014). Meanwhile, literature studies from previous research, books, and others are secondary data collection techniques. In contrast, primary data is obtained from in-depth interview transcripts using coding and data triangulation tests to measure validity because the research resources are the informants or the resource persons themselves. As for data analysis, this research uses the analysis by Miles and Huberman, which is commonly called the three components, namely data reduction, data presentation, and concluding (Miles et al., 2013).

\section{RESULTS AND DISCUSSION}

The intensity of using social media for teenagers is indeed increasing. Informants stated that they are very active in using social media, especially social media Instagram, YouTube, and Twitter. Informants use social media at least 6 hours a day which is usually used to simply watch YouTube, browse the internet or open their social media accounts. The purpose of informants using social media is not only to communicate but also to find entertainment. Social media is used as a place for informants to entertain themselves when they are bored. There are many ways for self-entertaining through social media, one of which is looking at idols. Social media is also used to seek information about informants' idols.

The three informants stated that they were cyberbullying perpetrators in the form of comments with unpleasant words on other people's social media. However, the three informants have never been victims of cyberbullying or have 
never been bullied on social media. Nevertheless, they claim that they are often cyberbullying against micro-celebrities. A micro-celebrity is someone who has gained popularity through content disseminated on social media.

These high school informants have different experiences and perspectives on cyberbullying they have ever done against micro-celebrities. Following are answers from the informants:

Based on an interview with Informant 1 on her experiences in committing cyberbullying against micro-celebrities, she stated:

"I often comment. At that time, I bullied Tupi Saravia, a celebrity, because she posted fake photos. I was annoyed because all the photos were lies. She travels around the world a lot that so many people follow her Instagram. But why would she try to edit the cloud image? So it seems she is lying. Is the traveling true or a lie? It could be edited, too."

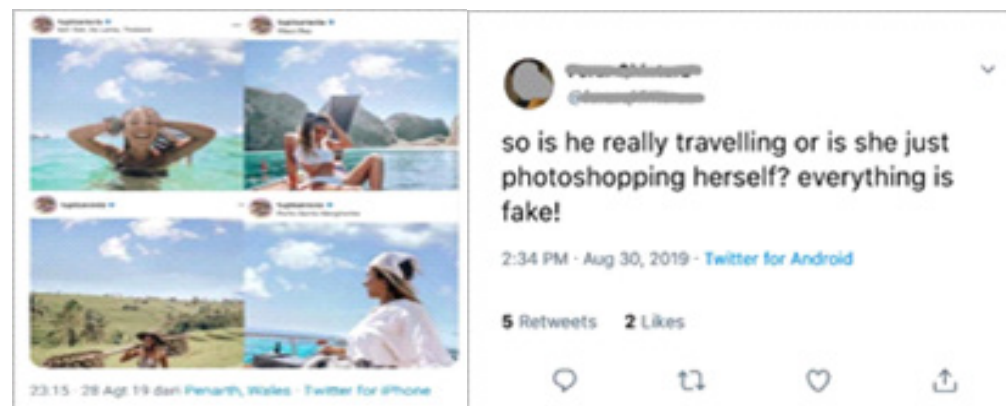

Figure 1. Tweet Screenshot from the Informant 1

Informant 1 committed cyberbullying against a traveling vlogger from Argentina, Tupi Saravia, for uploading fake photos on her social media. Tupi Saravia uploaded a photo on Twitter with a background of beautiful places but with the same cloud shape, which turned out to be a fake cloud that was edited using a photo editing application. Informant 1 felt compelled to comment on Tupi Saravia's Twitter post because she felt cheated by the fake photos.

The same thing was asked to Informant 2, and according to her,

"I often cyberbullying like Ria Ricis because sometimes her video vlogs at her YouTube are annoying and too trivial. I don't think her jokes are funny, but she has so many viewers."

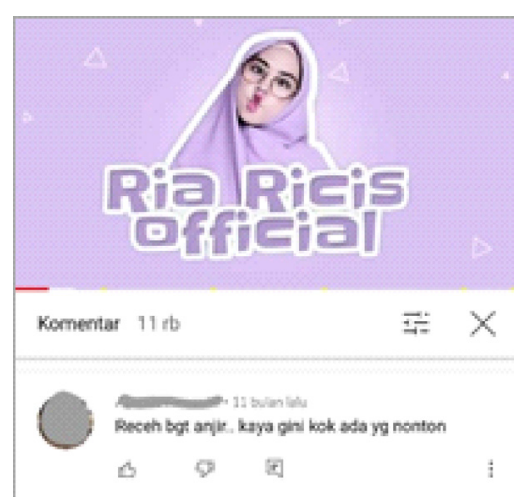

Figure 2. Screenshot on the comment

Informant 2 had also committed cyberbullying by commenting Ria Ricis, the YouTuber because she uploaded videos are not funny. Informant 2 then posted her comments on Ria Ricis'YouTube channel without thinking it over.

When researchers asked the same thing to Informant 3 who had ever done cyberbullying against celebrities, content is very controversial and intended to seek sensations. Cyberbullying is against Lucinta Luna because of his transformation from male to female and not admitting it to the public:

"I ever did cyberbullying celebrities who always look for sensations like Lucinta Luna as he transformed from male to female. It is proven and widely reported on social media. Nevertheless, the annoying thing is that he still doesn't want to admit it to the public". 

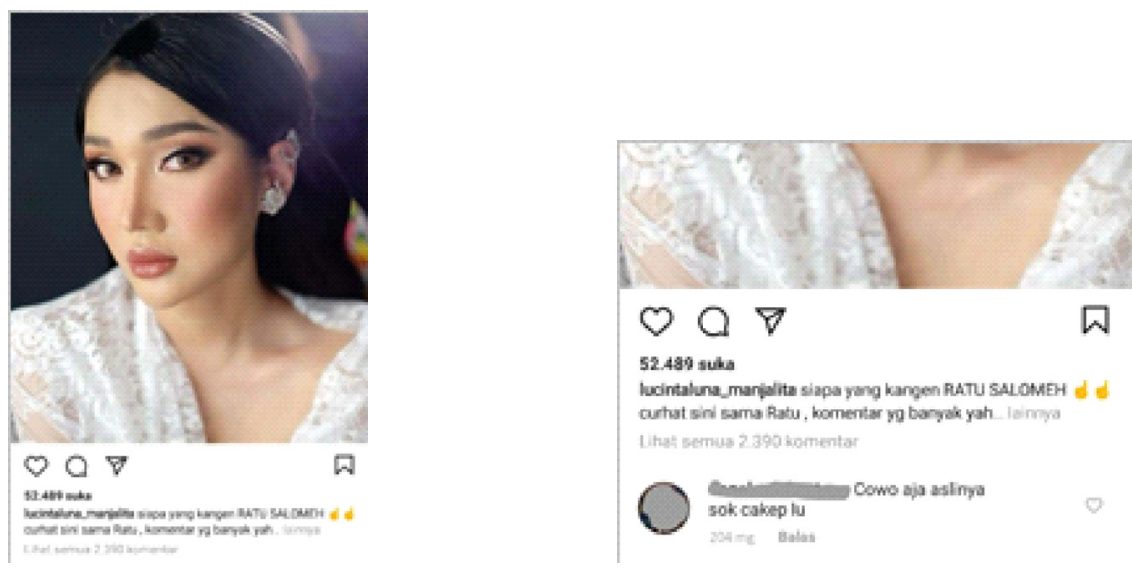

Figure 3. Screenshot of comments on Instagram

Based on the above three answers, these teenage informants admit that they often do cyberbully on social media, especially against micro-celebrities who disseminate fake contents and are dishonest to the public, so these teenagers felt annoyed cheated, and it made them post negative comments. Based on cyberbullying experiences that these three informants had ever done against Tupi Saravia, Ria Ricis dan Lucinta Luna, these celebrities are famous through social media, not through conventional mass media. Tupi Saravia is well-known as an Instagram celebrity with travel-themed content. Then, Ria Ricis gained popularity through her YouTube content with themes ranging from daily vlogs, challenges to collaborative videos with other celebrities. Meanwhile, Lucinta Luna is a dangdut singer whose name is viral because a video of having transgender surgery was spread on Instagram.

Based on the facts above, teenage informants do cyberbully against micro-celebrities who are instantly wellknown through their contents disseminated on social media. This is fine when the content is in the form of creation, but what happens a lot is that micro-celebrities are famous for their harmful contents, and these make micro-celebrities a victim of cyberbullying.

These teenagers have the same opinion about micro-celebrities. They think celebrities suddenly become famous not because of their work but because of sensation and controversial lies.

Informants 1 and 3 have the same opinion about micro-celebrities who are famous for harmful content,

"Yes, it's annoying. I totally disagree because they are famous for sensations and bad things. It seems unfair because many artists are desperately building careers starting from the lower level with positive work, but they are beaten by artists who are instantly famous, even richer."

Informants 1 and 3 disagree with artists who are instantly famous because it is very unfair to celebrities who work hard and provide positive benefits to society. Celebrities who are purely fighting for their careers with positive work are less famous than micro-celebrities famous for bad things. According to the informant, celebrities should benefit society in the entertainment world because celebrities are role models for many people.

However, informant 2 has a different opinion. She stated that instantly celebrities are nobody's business. There is no problem if the artists are famous for spreading sensation and lies on social media.

One of the micro-celebrities currently being discussed by the Indonesian people, especially by netizens on social media, is Barbie Kumalasari. Barbie Kumalasari is an artist who is intensely attending and invited to television shows and Indonesian celebrity YouTube channels. Not only being discussed a lot on social media, the three informants stated that Barbie Kumalasari is also a hot topic of conversation among teenagers at school. The three teenage informants shared the same opinion when asked about Barbie Kumalasari, who is a micro-celebrity.

According to informant 1, Barbie is not a new artist because, in the past, Barbie was already a soap opera player and often played a role as a housemaid, but at that time, her name was not yet widespread.

"She is an artist, but not very famous. And suddenly, she's really famous now. But actually she is a soap opera player already. But only playing the role of a maid. Then all of a sudden, she is exposed because her husband went to jail, even releasing her song though her voice is bad and it is inviting people to blaspheme against her." 


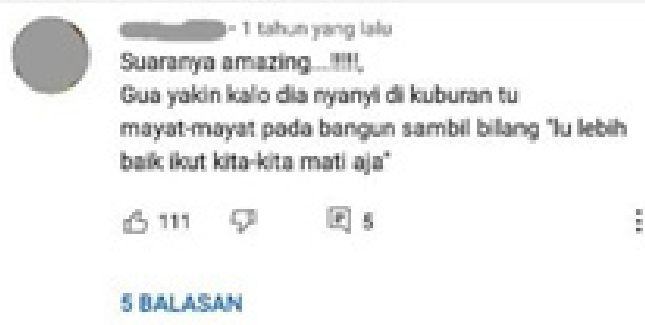

Figure 4. Screenshot of comment in YouTube

Informant 1 does cyberbully on Barbie Kumalasari youtube because Barbie is always present on social media to become a spokesperson for her husband Galih Ginanjar, charged by a defamation case against her former wife. Another reason is, Barbie often uploads photos with branded items that turn out to be fake. Barbie Kumalasari also released a song and switched professions as a singer even though her voice was not good.

Informant 2 has also been cyberbullying Barbie Kumalasari for doing plastic surgery that changed her face.

"He is famous for the case of the salted fish. She even was invited to TV. All parts of the face have plastic surgery, and it turns out really strange, I am annoyed when looking at her. Why a person like her is able to become a celebrity."

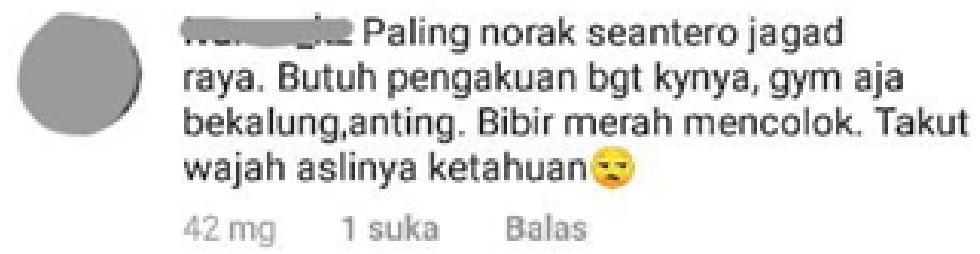

Figure 5. Screenshot of comment on Instagram

Meanwhile, informant 3 stated that Barbie Kumalasari became a micro-celebrity not because of her husband's case but because of her attitude and behavior. According to informant 3, Barbie became a victim of cyberbullying because of her inappropriate way of dressing, including her westernized way of speaking even though with the wrong grammar,

"Yes, that is not appropriate. However, she should not be bullied because of the salted fish case because it is her husband's case. But because of the way she dresses, her attitude also makes him bullied by netizens. When talking, she also speaks pretentiously in English even though she cannot".
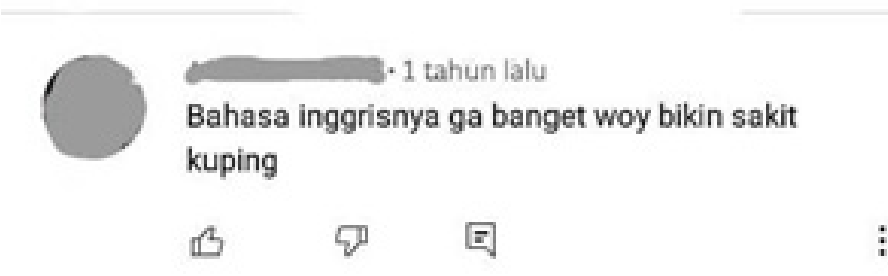

Figure 6. Screenshot of comment on YouTube

Informant 3 said that Barbie Kumalasari does not deserve if she is successful and famous just because of these negative things, even being invited as a resource on television.

The three teenage informants stated that Barbie Kumalasari used her husband's case to seek profit and become famous. However, the three informants answered with different explanations:

Informant 1 stated that Barbie is obvious in taking advantage of her husband's case. It is seen from the past that Barbie had often appeared on television when holding press conferences for her husband's case. However, now that her name has gone viral and is famous, Barbie has never appeared on television to discuss her husband's case. Even today, Barbie is busy building a career, starting from releasing songs to creating a YouTube account with controversial videos. 
"Yes, she used it because, at that time, she appeared to clarify her husband's case. But when she started getting invited to TV and had many bullies, suddenly she had never discussed her husband's case anymore. Instead, she continues to make songs for YouTube and other things."

Meanwhile, Informant 2 said that Barbie Kumalasari took advantage of her husband's case. Barbie released the song with an inappropriate voice. Informant 1 believes that Barbie released a song to invite blasphemy from netizens, thus making her name even more famous in the community.

"Maybe so, because just now she is composing songs that end up being bullied again. It looks like she likes being bullied so that her name is even more famous."

Informant 3 has the opinion that Barbie Kumalasari takes advantage of the tight situation. She took the opportunity to be famous from her husband's case. In other words, Barbie used her husband's case to promote herself in the Indonesian entertainment world.

"Yes, she took advantage because she seemed to take advantage of the tight situation. So, it is also to promote herself. "

Teenage informants who do cyberbully micro-celebrities can also follow the celebrity's account even though they usually should hate the celebrities they are bullying. Like the second informant who made inappropriate comments on Ria Ricis's YouTube account, she followed or subscribed to Ria Ricis's YouTube account.

"Ria Ricis is one of them that I commented on, but I also follow."

Meanwhile, it was different from informants 1 and 3 who did not follow the celebrity social media accounts they were bullying, but they still often searched for the latest news and issues about these micro-celebrities.

"I do not instantly follow famous artists like that. But I often just logged on to the account. "

"I don't follow such artists, but I like to see their gossips, always up-to-date."

All three answers stated that teenagers were cyberbullying micro-celebrities, but they still wanted to know the latest news about these celebrities by following their social media accounts. Likewise, when the three teenage informants were asked about their attitudes towards artists who were instantly famous for being victims of cyberbullying, they replied that they strongly disagreed with micro-celebrities. However, they continued to find out and constantly updated their knowledge by finding out on social media accounts. Alternatively, watching television shows that invite these microcelebrities. So that, indirectly, the teenagers took part in the process of becoming famous for micro-celebrities.

Still, in the context of cyberbullying against micro-celebrities, the three teenage informants offered different opinions when asked about the impact of cyberbullying on micro-celebrities.

All three answers stated that teenagers are cyberbullying micro-celebrities, but they still want to know the latest news about these celebrities by following their social media accounts. Likewise, when the three teenage informants were asked about their attitudes towards artists who were instantly famous for being victims of cyberbullying, they replied that they strongly disagreed with micro-celebrities. However, they continued to find out and constantly update their knowledge by finding out on social media accounts. Alternatively, watching television shows that invite these micro-celebrities. So that, indirectly, the teenagers took part in the process of becoming famous for micro-celebrities.

Still, in the context of cyberbullying against micro-celebrities, the three teenage informants offered different opinions when asked about the impact of cyberbullying on micro-celebrities.

Informant 1 confirmed that she did cyberbully, even though cyberbullying has a destructive psychological impact on micro-celebrities, but according to informant one, by commenting inappropriate, she helped micro-celebrity finances. The more often she does cyberbully, the more famous and better the celebrity will be.

"Yes, in my opinion, as a netizen, bullying Barbie Kumalasari is not psychologically appropriate, but financially we are helping her to become rich and become more famous." 
Meanwhile, informant 2 said that many micro-celebrities have been very successful even though their careers started as a sensation and became victims of cyberbullying. However, according to informant 2, there is no problem for her if micro-celebrities seek income by spreading sensations. According to her, the life of these micro-celebrities is not her concern. Even so, informant two still does not justify celebrities who spread harmful content on social media,

"As far as I know, there are a lot of in stantly famous artists who are now well known and already rich because they were initially blasphemed on social media. For example, Awkarin. She found that the content is not useful, but if someone can make money, why not? It is up to her."

Based on the answers above, teenagers often commit cyberbullying because they think this is not detrimental to the celebrities who are victims. The three answers of the informants both stated that cyberbullying harmed the victim from a psychological perspective. The victim must have felt sad and anxious because inappropriate words were being said on their social media accounts. However, teenagers believe that their cyberbullying is very beneficial for the victim from a financial perspective. The more negative comments sent, it will make micro-celebrities more viral and famous, even flooded with endorsements until they are invited to television shows.

In line with research conducted (Situmorang, 2019), being a victim of cyberbullying has recorded disadvantages and advantages for its victims. In Indonesia, being one of the victims of cyberbullying on social media is unique because the effect can be viral and well-known. This is very influential on the financial income they get every month:

Based on the results of interviews and observations, it can be concluded that teenagers do cyberbully in the form of negative comments that show teenagers' aggressiveness towards micro-celebrities. It started from a micro-celebrity that uploads content on social media. The contents consist of sensations and controversy that trigger teenagers' reaction to comment negatively in the comments column. The content of comments submitted by teenagers is a form of disapproval of the harmful content.

Teenagers are aware of the existence of regulations regarding cyberbullying on social media, namely the ITE Law Article 27 paragraph 3, which states that "the prohibition of distributing, transmitting, making electronic information and/ or electronic documents accessible, contains: defamation." Nevertheless, teenagers have their way, which does not violate the ITE Law, namely by committing cyberbullying using fake accounts or accounts that are not clear who the owner is. It is just for the sake of satisfying his evil desire for micro-celebrities.

On the other hand, some micro-celebrities deliberately take advantage of the negative comments on their social media. Alternatively, in other words, they deliberately present themselves as victims of bullying on social media. This is usually called a created condition or condition, which means that people see reality as a fact even though it is their creation and enjoys it. The goal is to create controversy to increase popularity (Citra, 2019). Due to this fact, teenagers are increasingly eager to do cyber bullying by commenting negatively on social media. Even in this digital era, there are more and more people who take advantage of this phenomenon. Many artists are instantly famous for spreading sensations. This makes more and more objects to use as a reason for cyberbullying.

Cyberbullying on micro-celebrities has now become a habit of Indonesian society, especially teenagers. Bullying on social media is no longer a rare thing. Teenagers do not feel detrimental to the victim in cyberbullying even though cyberbullying is very dangerous for a person's psychology and can even cause suicidal desires and depression. However, teenagers think that cyberbullying is beneficial for Micro-celebrities because it is beneficial in terms of finances. Teenagers also feel it unfair that famous and viral micro-celebrities outdo celebrities who have built their careers from zero simply because of the sensation.

Based on the results of a literature studies collection, previous research, interview data, and summarized information, the researcher then analyzed the motives of teenagers for cyberbullying to micro-celebrities on social media. The motives of teenagers who engage in cyberbullying are categorized into several phases, including the motive for disliking micro-celebrity personalities, intending to insult with unethical negative comments, jealousy, and incitement towards micro-celebrities, feeling that micro-celebrities do not deserve their popularity.

The first motive for teenagers to do cyber bullying is their dislike of micro-celebrities. The dislike could be because the content spread by micro-celebrities is not following expectations or because the content uploaded on microcelebrity's social media is harmful content. In terms of content that contains sensation, controversy, or lies, teenagers will comment negatively on the micro celebrity's social media accounts. This dislike motive can also be caused by teenagers disagreeing with the popularity that micro-celebrities get from harmful content uploaded on social media.

The second motive of teenagers, namely, the motive, intends to insinuate with unethical negative comments. Teenagers' hatred of micro-celebrities causes this motive. Teenagers send negative comments containing satire in criticism, insults, and body shaming, hoping that micro-celebrities can read these comments. Teenagers will feel satisfied because they have succeeded in insinuating the life of a micro-celebrity. 
The third motive of cyberbullying is jealousy and incitement. The purpose of this motive is that teenagers feel envious because micro-celebrities post something on social media that in real life is difficult for teenagers to get. For example, micro-celebrities post photos of luxury cars on social media. Teenagers feel envious because of the wealth that micro-celebrities get through harmful content, and teenagers cannot get that in real life.

The last motive behind cyberbullying, micro-celebrities do not deserve success compared to other celebrities. According to teenagers, micro-celebrities famous for their harmful content, and victims of cyberbullying do not deserve their popularity. It is unfair for celebrities who struggle to build careers with positive and beneficial creations to society. Teenagers feel that micro-celebrities do not deserve the benefits of being a celebrity, especially financial ones.

\section{CONCLUSION}

Based on the results and discussion, it can be concluded that cyberbullying by teenagers against micro-celebrities is in the form of negative comments in the comments column. These micro-celebrities are being bullied because they are considered to have gained popularity by spreading harmful content. Teenagers disagree with celebrities who are instantly famous because it is very unfair to celebrities who have creations and positively benefit society. Celebrities who are purely fighting for their careers with positive work are less famous than micro-celebrities famous for bad things. According to the informant, celebrities should be able to provide benefits to society in the entertainment world.

Cyberbullying harms its victims, namely in the form of psychological harm. Victims can feel sad, depressed, and even want to commit suicide. However, according to teenagers, cyberbullying also has a positive impact on microcelebrities, namely financial benefits. Since the effect of being a cyberbullying victim in Indonesia is unique, victims who are bullied will become more viral and famous.

Teenagers realize that cyberbullying is wrong. They already know the rules regarding the prohibition of cyberbullying, namely the ITE Law Article 27 paragraph 3. Even so, teenagers have their way of cyberbullying, which, according to them, does not violate the rules by using fake accounts to satisfy their hateful motives towards micro-celebrities.

\section{REFERENCES}

[1] Ardianto, E., \& Komala, L. (2004). Komunikasi massa: suatu pengantar. Simbiosa Rekatama Media.

[2] Cassidy, W., Faucher, C., \& Jackson, M. (2013). Cyberbullying among youth: A comprehensive review of current international research and its implications and application to policy and practice. School Psychology International, 34(6), 575-612. https://doi.org/10.1177/0143034313479697

[3] Citra, D. H. (2019). Mengapa Netizen Senang Bully Artis - kumparan. Retrieved from https://kumparan.com/ kumparanhits/mengapa-netizen-senang-bully-artis-1qpP2IFurQ9

[4] Creswell, J. W. (2017). John W, Creswell, Research Design: Qualitative, Quantitative, and Mixed Methods Approaches. In Journal of Social and Administrative Sciences (Vol. 4, Issue June, pp. 3-5).

[5] Fitransyah, R. R., \& Waliyanti, E. (2018). Perilaku Cyberbullying Dengan Media Instagram Pada Remaja Di Yogyakarta. Indonesian Journal of Nursing Practice, 2(1), 36-48. https://doi.org/10.18196/ijnp.2177

[6] Fronika, W. (2019). Pengaruh Media Sosial Terhadap Sikap Remaja. Fakultas Ilmu Pendidikan Universitas Negeri Padang Email, 1-15. https://osf.io/g8cv2/download

[7] Garman, A. (2014). Ordinary people and the media: The Demotic Turn. Ecquid Novi: African Journalism Studies, 35(1), 109-112. https://doi.org/10.1080/02560054.2014.886661

[8] Ireland, J. L., Birch, P., \& Ireland, C. A. (2018). The Routledge International Handbook of Human Aggression: Current Issues and Perspectives. In The Routledge International Handbook of Human Aggression: Current Issues and Perspectives (pp. 1-432). https://doi.org/10.4324/9781315618777

[9] Kaplan, A., \& Haenlein, M. (2010). Users of the World, Unite! The Challenges and Opportunities of Social Media. Business Horizons, 53, 59-68. https://doi.org/10.1016/j.bushor.2009.09.003

[10] Katadata.co.id (2020). Jumlah Pengguna Internet di Indonesia Capai 196, 7 Juta Retrieved from https://databoks. katadata.co.id/datapublish/2020/11/11/jumlah-pengguna-internet-di-indonesia-capai-1967-juta

[11] Kowalski, R., Giumetti, G., Schroeder, A., \& Lattanner, M. (2014). Bullying in the Digital Age: A Critical Review and Meta-Analysis of Cyberbullying Research Among Youth. Psychological Bulletin, 140. https://oi.org/10.1037/ a0035618

[12] Kowalski, R., \& Limber, S. P. (2013). Psychological, physical, and academic correlates of cyberbullying and traditional bullying. The Journal of Adolescent Health : Official Publication of the Society for Adolescent Medicine, 53(1 Suppl), S13-20. https://doi.org/10.1016/j.jadohealth.2012.09.018

[13] Marsinun, \& Riswanto. (2020). Perilaku Cyberbullying Remaja di Media Sosial Youth Cyberbullying Behavior in Social Media. 12(2), 98-111. 
[14] Marwick, A., \& Boyd, D. (2011). To see and be seen: Celebrity practice on Twitter. Convergence, 17(2), 139-158. https://doi.org/10.1177/1354856510394539

[15] McQuail, D. (2011). Teori Komunikasi Massa McQuail Edisi Buku Denis McQuail.

[16] Miles, M. B., Huberman, A. M., \& Saldana, J. (2013). Qualitative Data Analysis: A Methods Sourcebook. SAGE Publications. https://books.google.co.id/books?id=p0wXBAAAQBAJ

[17] Mutma. (2017). Konferensi Nasional Komunikasi. Konstruksi Media Republika Online Terhadap Pidato Pelantikan Gubernur DKI Jakarta Anies Baswedan, 01(01), 657-667. http://pknk.org/index.php/PKNK/article/view/47/52

[18] Natalia, E. C. (2016). REMAJA, MEDIA SOSIAL DAN CYBERBULLYING Latar Belakang para remaja sebagai ajang untuk terkoneksi dengan media sosial . orang alat untuk melakukan. Jurnal Ilmiah Komunikasi, 5, $119-137$. http://journal.wima.ac.id/index.php/KOMUNIKATIF/article/view/991/944

[19] Olweus, D. (2012). Cyberbullying: An overrated phenomenon? European Journal of Developmental Psychology, 9(5), 520-538. https://doi.org/10.1080/17405629.2012.682358

[20] Pramiyanti, A., Putri, I. P., \& Nureni, R. (2014). Motif remaja dalam menggunakan media baru (studi pada Remaja di Daerah Sub-Urban Kota Bandung). KomuniTi, 6(2), 95-103. http://journals.ums.ac.id/index.php/komuniti/ article/download/2783/1776

[21] Pratomo, Y. (2019). APJII: Jumlah Pengguna Internet di Indonesia Tembus 171 Juta Jiwa. Retrieved from https:// tekno.kompas.com/read/2019/05/16/03260037/apjii-jumlah-pengguna-internet-di-indonesia-tembus-171-juta-jiwa

[22] Rosen, L. H., DeOrnellas, K., \& Scott, S. R. (2017). Teachers' Perceptions of Bullying: A Focus Group Approach. Journal of School Violence, 16(1), 119-139. https://doi.org/10.1080/15388220.2015.1124340

[23] Sadasri, L. M., \& Sosio, J. (2017). Micro-Celebrity On New Media Self-Presentation Study On Micro-Celebrity 'S Vlog. http://dx.doi.org/10.33299/jpkop.21.2.1218

[24] Sartana, \& Afriyeni, N. (2017). Perilaku Perundung Maya (Cyber Bullying) Pada Remaja Awal. Journal Psikologis Insight, 1(1), 25-39. https://ejournal.upi.edu/index.php/insight/article/download/8442/5299

[25] Senft, T. M. (2008). Camgirls: Celebrity and Community in the Age of Social Networks. Lang. https://books.google. co.id/books?id=u9w-XY\%5C_gU2gC

[26] Simangunsong, A. O. F. (2018). Fenomena Mikroselebriti di Instagram: Analisis Semiotika Presentasi Diri Karin Novilda. In Isu-isu Masyarakat Digital Kontemporer (pp. 28-53).

[27] Situmorang, D. (2019). Menjadi Viral Dan Terkenal Di Media Sosial, Padahal Korban Cyberbullying: Suatu Kerugian Atau Keuntungan? JPPP - Jurnal Penelitian Dan Pengukuran Psikologi, 8(1), 12-19. https://doi. org/10.21009/jppp.081.02

[28] Waluyo, A. P. (2019). Barbie Kumalasari Akui Jadi Terkenal Setelah Kasus Bau Ikan Asin. Retrieved from https://wartakota.tribunnews.com/2019/09/29/barbie-kumalasari-akui-jadi-terkenal-setelah-kasus-bau-ikan-asin 
